\title{
Internet Access as an Independent Human Right: a Palpable Consequence of the Covid-19 Pandemic?
}

\author{
Kunal Bilaney* \& Gauri Thampi**
}

\begin{abstract}
The onslaught of the COVID-19 pandemic has established a new world order which is heavily reliant upon the internet for public access to health, education, employment, and recreation among other services. Furthermore, the growing dependence on technology has also been crucial in the battle against the pandemic. However, despite the irreplaceable utility of the technology, state practices have remained divergent in this field. While a multitude of nations have recognized internet access as a fundamental right, many nations imposed unjustified restrictions on their citizens during the pandemic and some even failed to provide affordable access to internet facilities, which has proven to be detrimental to the realisation of basic individual rights. As the world makes a transition from a pandemic, the intensifying reliance upon the internet bas given rise to a need to recognise access to the internet as an independent human right. In light of the above, the present paper seeks to elucidate how access to the internet has emerged as a necessity in the backdrop of a pandemic and examine how the differing state responses in this context have been violating individual rights. The paper also delves into how internet access is being dealt with under the existing international and domestic regime. Further, the authors attempt to philosophically justify a human right to internet access and politically conceptualise the same, and argue in favour of recognition of internet access as an independent buman right under international law.
\end{abstract}

\section{Introduction}

For a layperson, the COVID-19 pandemic has brought into perspective how a utility can be transformed into an essential lifesaving facility overnight while normalcy ceased to exist. According to international law, this might be one of the fastest factual developments in the process of evolution of a human right. In 2016, the UN declared internet access as a human right recognizing its indispensable nature to realize several human rights in the backdrop of the ongoing events of the Arab spring. ${ }^{1}$ However,

* Kunal Bilaney is an advocate practicing criminal law before the Honorable High Court of Bombay as well as other subordinate courts across the city of Mumbai, Maharashtra, India. He is a B.B.A. LL.B. (Hons) graduate from Alliance University, Bengaluru, India. He can be reached at kkbilaney@gmail.com.

** Gauri Thampi is a human rights lawyer and is currently working as a Fellow at Migration and Asylum Project focusing on providing legal representation to asylum seekers before UNHCR. She completed her B.B.A. LL.B. (Hons) from Alliance University, Bengaluru, India. She can be reached at gaurithampi@gmail.com.

1 Adam Clark Estes, 'The UN declares Internet Access as a Human Right, The Atlantic, 6 June 2011, available at https://www.theatlantic.com/technology/archive/2011/06/united-nations-wikileaks-internet-humanrights/351462/, accessed on 3 July 2020. 
the declaration was not the ultimate step to elevate and establish the status of internet access as a human right, and since then at state and international levels, there have been several developments towards recognizing the human right to internet access. ${ }^{2}$

In terms of context, if Arab Spring was the foremost catalyst in the progression of internet access as a human right, the pandemic has further solidified this revamped right, its nature, and urgency. The pandemic has abdicated the status quo and restored a new world order, where internet technology is dominating and leading everyday life, and the effect of which will seep into the post-pandemic world as well. ${ }^{3}$ Therefore, the reliance on the internet has suddenly undergone a paradigm shift giving rise to a new factual basis and context for its emancipation as a human right, specifically as an independent human right by arguing that internet access is no longer merely associated with pursuing other human rights such as freedom of expression, information and equality.

In the light of the above, the discussion in this paper is divided into three parts where the first part will firstly, elucidate how internet technology has become a crucial tool in the post-pandemic world, and secondly, analyze how irrespective of its overwhelming utility, states are failing to ensure internet access to citizens by bringing into purview the recent internet shutdowns, and failure to provide affordable access to the internet. Further, the second part will examine the current status of recognition and legal protection afforded to internet access at the international and domestic levels. Lastly, the third part of the paper will philosophically justify a human right to internet access and politically conceptualize the same, and further, defend the proposal by the authors to elevate internet access as an independent human right.

\section{Pandemic and the Digital World}

\subsection{The Digital Shift}

The pandemic has brought in a paradigm shift in the way people use the internet. While physical spaces have become unavailable, internet technology is providing solace by mirroring the same activities in the virtual world. With the outbreak of the pandemic, big tech companies such as Google, Facebook, and Amazon have been able to sustain and further expand their profits. ${ }^{4}$ In the backdrop of failing businesses, only a few companies have been able to capitalize on the self-isolation such as Netflix, Zoom, Google Classroom, House party, and Google Duo. ${ }^{5}$ All of them are tech companies

Thomas D. Sniadecki, 'A Road compared to a Horse: An examination of Internet Access as a Human Right', Honors Projects, 2014, p. 283, available at https://scholarworks.gvsu.edu/honorsprojects/283, accessed on 4 July 2020.

3 Lucy Handley, 'Here's how our digital lives might look in a post-pandemic world', CNBC, 14 April 2020, available at https://www.cnbc.com/2020/04/14/heres-how-our-digital-lives-might-look-in-a-postcoronavirus-world.html, accessed on 3 July 2020.

4 Elizabeth Lopatto, 'In the Pandemic Economy, tech companies are raking it in', The Verge, 30 July 2020, available at https://www.theverge.com/2020/7/30/21348652/pandemic-earnings-antitrust-googlefacebook-apple-amazon, accessed on 30 July 2020.

5 Ella Koeze and Nathaniel Popper, 'The Virus Changed the Way We Internet', The New York. Times, 7 April 
providing entertainment, education, remote work, and communication facilities.

As outdoor recreational activities have completely been out of the picture, OverThe-Top (OT'T) and video streaming services like Netflix, YouTube and Amazon Prime Video have witnessed a surge in their subscribers and viewers. ${ }^{6}$ The rigorous lockdowns have compelled the companies to engage their workforce remotely from home which has led to the increasing popularity of online video calling platforms like Microsoft Teams, Hangouts, and Zoom. ${ }^{7}$ The schools and universities have revamped and equipped themselves to conducting classes and examinations online thereby transforming the structure of the education system and its future. ${ }^{8}$ As more people have stayed home, grocery services and other retail shopping have also shifted online. ${ }^{9}$ Further, consultations with doctors are happening online, and mental health treatment and support groups are flourishing online. ${ }^{10}$ As places of worship have shut down, religious sermons and worship have also moved to the virtual world. ${ }^{11}$ Online conferences, workshops, webinars, workout groups, live dance and music classes have become the new normal. While gatherings and recreational activities in physical space have become a thing of the past, technology has taken over to bridge this gap to ease human life and ensure necessary contact.

Apart from the reliance on internet technology to access essential services and facilities, the internet has been at the forefront in the fight against the pandemic as well. By establishing digital surveillance and health initiatives through various applications and websites, contract tracing and health care services are being provided online by different countries. ${ }^{12}$ India, for example, has come up with Aarogya Setu, an application that

2020, available at https://www.nytimes.com/interactive/2020/04/07/technology/coronavirus-internetuse.html, accessed on 10 July 2020.

6 'Global OTT Market to rise and hit a revenue of $\$ 438.5$ Billion during the Covid-19 Catastrophe', Cision PR Newswire, 14 July 2020, available at https://www.prnewswire.co.uk/news-releases/global-over-thetop-ott-market-to-rise-and-hit-a-revenue-of-438-5-billion-during-the-covid-19-catastrophe-researchdive-860906448.html, accessed on 20 July 2020.

7 Mohit Joshi, 'Who will be the winners in a Post-Pandemic economy?', World Economic Forum, 20 April 2020, available at https://www.weforum.org/agenda/2020/04/post-pandemic-economy-favour-fastestmovers/, accessed on 15 July 2020.

8 Cathy Li and Farah Lalani, 'The Covid-19 Pandemic has Changed Education Forever', World Economic Forum, 29 April 2020 available at https://www.weforum.org/agenda/2020/04/coronavirus-educationglobal-covid19-online-digital-learning/ accessed on 10 July 2020.

9 Aine Cain, 'Amazon's online grocery sales tripled as people stayed home amid the Corona Virus Pandemic', Business Insider, 31 July 2020, available at https://www.businessinsider.in/retail/news/amazons-onlinegrocery-sales-tripled-as-people-stayed-home-amid-the-coronavirus-pandemic/articleshow/77273685. cms, accessed on 31 July 2020.

10 Shibu Tripathi, '500\% spike in online medical consultation under lockdown: Practo Report', Business Standard, 22 June 2020, available at https:/ /www.business-standard.com/article/current-affairs/500-spikein-online-medical-consultation-under-lockdown-practo-report-120062201323_1.html, accessed on 15 July 2020.

11 Casey Cep, 'The Gospel in a Time of Social Distancing', The New Yorker, 29 March 2020, available at https://www.newyorker.com/news/on-religion/the-gospel-in-a-time-of-social-distancing, accessed on 15 July 2020.

12 Ravi Pratap Singh, Mohd Javaid, Abid Haleem \& Rajeev Suman, 'Internet of things applications to fight against COVID-19 Pandemic', Diabetes \& Metabolic Syndrome: Clinical Research \& Reviews p.521, volume 14, 2020. 
disseminates all COVID-19 related information, and carries out the tracking of patients as well as risk assessment. ${ }^{13}$ Apart from this, China's Chinese Health Code System, UAE's TraceCovid, Switzerland's Swiss Covid, Singapore's Trace Together, Philippines Stay Safe, Japan's COCOA, Italy's Immuni, and Ireland's Covid Tracker are the applications launched by some of the countries, among many others adopting combinations of technology incorporating Bluetooth, GPS services and other methods for tracking and tracing the virus. ${ }^{14}$ These services have proven to be extremely reliable and necessary in the fight against the pandemic to contain the spread and flatten the curve. Moreover, it can help in foreseeing the peak periods, predicting the vulnerable areas, and sourcing out trustworthy information. ${ }^{15}$ Therefore, the dependence and growth of internet technologies post the onslaught of the pandemic is deeper than ever.

\subsection{State Practices Endangering Human Rights}

With no regard to the increasing dependence on internet access, many nations have unexpectedly imposed internet shutdowns without proper justifications. ${ }^{16}$ Although it has been more than four months (at the time of writing of this paper) since COVID-19 has been characterized as a pandemic ${ }^{17}$, states have continued to restrict internet access in many areas. In India, there have been more than 380 internet shutdowns since 2012..$^{18}$ Owing to this, India has been termed as the global capital of internet shutdowns. ${ }^{19}$ During the pandemic, the Indian government decided to continue with the internet shutdown in the state of Jammu and Kashmir that was imposed in 2019. As a result of which, the state's health services have been affected significantly. Moreover, considering that Jammu and Kashmir is one of the worst-affected Indian states, even contract tracing has been severely impeded due to the shutdown. ${ }^{20}$ Doctors have been unable to circulate information about the virus and have been unable to communicate with the patients. Although owing to the Bhasin judgment, in theory, the internet shutdown in Jammu and Kashmir has been lifted by providing $2 \mathrm{G}$ internet services, in practice,

13 Andrew Clarence, 'Aarogya Setu: Why India's Covid-19 contact tracing app is controversial', BBC News, 15 May 2020, available at https://www.bbc.com/news/world-asia-india-52659520, accessed on 5 July 2020.

14 Patrick Howell, Tate Ryan-Mosley \& Bobbie Johnson, 'A Flood of Corona Virus Apps are tracking us. Now it's time to keep track of them', MIT Technology Review, 7 May 2020, available at https:/ / www.technologyreview. com/2020/05/07/1000961/launching-mittr-covid-tracing-tracker/ accessed on 16 July 2020.

15 Nan Jiang \& Julie Ryan, 'How does digital technology help in the fight against Covid-19?', World Bank Blogs, 29 May 2020, available at https://blogs.worldbank.org/developmenttalk/how-does-digital-technologyhelp-fight-against-covid-19, accessed on 16 July 2020.

16 'End Internet Shutdowns to Manage COVID-19', Human Rights Watch, 31 March 2020, available at https:/ / www.hrw.org/news/2020/03/31/end-internet-shutdowns-manage-covid-19, accessed on 4 August 2020.

17 'Archived: WHO Timeline - COVID-19', World Health Organization, 27 April 2020, available at https:// www.who.int/news-room/detail/27-04-2020-who-timeline---covid-19, accessed on 4 August 2020.

18 Ibid.

19 Ravi Krishnani, 'India: The World Leader in Internet Shutdowns', CNN, 14 December 2019, available at https://edition.cnn.com/2019/12/14/opinions/india-world-leader-in-internet-shutdowns/index.html, accessed on 4 August 2020.

20 Athar Parvaiz, 'Kashmir Internet Blackouts Hinder Health Services, Contact Tracing', Reuters, 20 May 2020, available at https://www.reuters.com/article/us-health-coronavirus-india-tech-trfn/kashmirinternet-blackouts-hinder-health-services-contact-tracing-idUSKBN22W052, accessed on 4 July 2020. 
however, $2 \mathrm{G}$ internet services have remained ineffective. ${ }^{21}$

In Myanmar, an estimated 1.4 million people have been restricted from internet access. ${ }^{22}$ What has been termed as the 'longest internet shutdown' in the world, has also shockingly led to many people in Myanmar remaining unaware of the COVID-19 pandemic. ${ }^{23}$ In addition to impeding the provision of many essential services, the internet shutdown has also endangered the safety of many people, as the international community is unable to provide any sort of support during the ongoing armed conflict between the military and a militant group in Myanmar. ${ }^{24}$ The problem has been aggravating as it has been reported that the Myanmar government has decided to restrict internet access till August $2020 .{ }^{25}$ The internet shutdown is not only hampering the provision of medical aid, but is also impeding the collection of accurate information about the virus, and is further affecting the monitoring of online abuses.

In Bangladesh, the number of COVID-19 infected persons has been rising among the Rohingya refugees. The shutdown has endangered the safety of over a million people and is also obstructing the humanitarian groups from providing assistance during the subsisting pandemic. ${ }^{26}$ Furthermore, the internet restrictions have impeded the effective circulation of crucial information, such as the importance of masks and handwashing, among the people in Bangladesh. ${ }^{27}$ Moreover, in the absence of accurate information, misinformation has started to spread like wildfire. ${ }^{28}$ Such a shutdown has led to communication gaps during a time when access to information is considered a lifesaving tool. In addition to the existing problems of declining health care infrastructure, water shortages and food deficiencies, the Rohingyas are also unable to receive any accurate information about their repatriation as the issue of statelessness persists. ${ }^{29}$

21 Raman Jit Singh Chima and Berhan Taye, 'Supreme Court of India Fails to Restore High-Speed Internet in Jammu and Kashmir during COVID-19', Access Now, 14 May 2020, available at https://www.accessnow. org/supreme-court-of-india-fails-to-restore-high-speed-internet-in-jammu-and-kashmir/, accessed on 4 August 2020.

22 Cape Diamond, 'Does Myanmar Internet Shutdown Risk a COVID-19 Outbreak?', DW, 24 June 2020, available at https://www.dw.com/en/does-myanmar-internet-shutdown-risk-a-covid-19outbreak/a-53925095, accessed on 4 August 2020.

23 'Myanmar: End World's Longest Internet Shutdown', Human Rights Watch, 19 June 2020, available at https://www.hrw.org/news/2020/06/19/myanmar-end-worlds-longest-internet-shutdown, accessed on 4 August 2020.

24 Ibid.

25 'Myanmar: End Unlawful Internet Restrictions', Human Rights Watch, 27 July 2020, available at https:// www.hrw.org/news/2020/07/27/myanmar-end-unlawful-internet-restrictions, accessed on 4 August 2020 .

26 'Bangladesh: Internet Ban Risks Rohingya Lives', Human Rights Watch, 26 March 2020, available at https:// www.hrw.org/news/2020/03/26/bangladesh-internet-ban-risks-rohingya-lives, accessed on 4 August 2020 .

27 Nazmun Naher Shishir, 'In Bangladesh, Internet Restrictions, Rumours Worsen COVID-19 Fears', Firstpost, available at https://www.firstpost.com/long-reads/in-bangladesh-internet-restrictions-rumoursworsen-covid-19-fears-in-rohingya-camps-8514181.html, accessed on 4 August 2020.

28 Michael Sullivan, 'Leaders Want Internet Ban Lifted in Rohingya Area as COVID-19 Misinformation Spreads', NPR, 24 June 2020, available at https://www.npr.org/2020/06/24/882678469/leaders-wantinternet-ban-lifted-in-rohingya-area-as-covid-19-misinformation-spr, accessed on 4 August 2020.

29 Sage Cheng, Felicia Anthonio and Berhan Taye, '\#KeepItOn: Internet Shutdowns Puts Lives at Risk during COVID-19', Accessnow, 26 May 2020, available at https://www.accessnow.org/keepiton-internet- 
Not only are many states engaged in imposing internet shutdowns, but many are also failing to provide affordable internet access during the periods of lockdown. For instance, in the United Kingdom, the government's inability to provide affordable internet access has created a 'digital divide' among the citizens. ${ }^{30}$ The situation has further aggravated as the refugees and the asylum seekers are finding it extremely difficult to meet the basic needs required for their sustenance, owing to the lack of internet access and digital resources. ${ }^{31}$

If this pandemic has taught the international community anything, it is the importance of internet access due to the ever-increasing dependence upon it. Many humanitarian groups have called for the end of such internet shutdowns in these countries; however, their efforts seem to have gone in vain. ${ }^{32}$ Even the World Health Organization has been urged to publicly denounce internet shutdowns. ${ }^{33} \mathrm{It}$ is evident that in the backdrop of the subsisting pandemic, internet access has risen to be a vital aspect of basic human life. Furthermore, a prudent presumption would be that it will continue to be so, even in the post-pandemic world. Owing to this, it is contended that it is high time that internet access is regarded as a human right to prevent violation of basic human rights.

\section{Legal Protection of Internet Access}

Deriving a new Human right in international law can be carried out either through accommodating it within the expanded meaning of existing human rights, i.e. as an implied right or through introducing a stand-alone human right with its accompanying justifications. ${ }^{34}$ Since the current paper argues for the recognition of the internet as an independent human right, before proceeding to the argument, it becomes exceedingly relevant to reevaluate the existing status of recognition attached to internet access under international law and domestic laws, or rather how internet access is being classified, protected and ascertained by international law and laws of different countries.

\subsection{Approach at the International Level}

In 2011, UN Human Rights Council adopted the report of the Special Rapporteur on

shutdowns-put-lives-at-risk-during-covid-19/, accessed on 4 August 2020.

30 Annie Kelly, 'Digital Divide "Isolates and Endangers" Millions of UK's Poorest, The Guardian, 28 April 2020, available at https://www.theguardian.com/world/2020/apr/28/digital-divide-isolates-andendangers-millions-of-uk-poorest, accessed on 4 August 2020.

31 'Refugees without Phones "Unable to get Support in Lockdown", BBC News, 22 April 2020, available at https://www.bbc.com/news/uk-england-bristol-52366921, accessed on 4 August 2020.

32 Hillary Leung, 'Rights Group Calls for Moratorium on Internet Shutdowns Amid Coronavirus Outbreak', Time, 31 March 2020, available at https://time.com/5812921/human-rights-watch-internet-shutdowncoronavirus/, accessed on 4 August 2020.

33 Riyaz U1 Khaliq, 'WHO Urged to Seek End to Internet Shutdown in S. Asia', A A, 27 May 2020, available at https://www.aa.com.tr/en/asia-pacific/who-urged-to-seek-end-to-internet-shutdown-in-s-asia/1854861, accessed on 4 August 2020.

34 Basak Cali, 'The Case for the Right to Meaningful Access to Internet as a Human Right in International Law' in Andreas von Arnauld \& Kerstin von der Decken (eds), The Right To Internet Access, Cambridge University Press, UK, 2020. 
the Promotion and Protection of the right to freedom of Opinion and Expression declaring the right to Internet access as a Human Right..$^{35}$ The UN High Commissioner for Human Rights held that human rights are equally valid online as well as offline. ${ }^{36}$ The same right was further upheld in 2012, 2014 and 2016. ${ }^{37}$ In 2016, with the adoption of the resolution on the Promotion, Protection and Enjoyment of human rights on the Internet by the Human rights Council, the UN called out countries to address their concerns about internet security in line with international human rights obligations in order to ensure the protection of freedom of expression, freedom of association, the right to privacy and other online human rights. ${ }^{38}$ Therefore, in all the above instances, the right to internet access was considered an inseparable aspect of freedom of speech and expression and other fundamental human rights. This was only an enumeration of well-established rights for the realization of which the internet has become an indispensable means. ${ }^{39}$ This does not in any way amount to the declaration or emergence of a new human right.

The European Parliament also adopted the right in the same line of UN, as it was stated that unrestricted and secure internet access must be provided and the countries must ensure that freedom of expression is not subjected to arbitrary restrictions. ${ }^{40}$ The European Court of Human Rights in its 2012 decision stated that the freedom of access to the internet is an integral part of freedom of speech and that any unproportionate curtailment of internet access that hinders access to other websites is contrary to freedom of speech. ${ }^{41}$

\subsection{Approach of States}

Not all countries have recognized internet access as a 'right', and among the countries that have recognized the importance of internet access, there is no visible uniformity in their laws and policies, nature of recognition of the 'right', and subsequent implementation of internet access. Greece, Portugal and Ecuador are the only countries that have provided for the codification of the right to internet access as a fundamental right in their respective Constitutions. ${ }^{42}$ These countries through their constitutional codification gave the right an autonomous status, independent of the pre-existing

\footnotetext{
35 Frank La Rue, 'Report of the Special Rapporteur on the promotion and protection of the right to freedom of opinion and expression', UNHRC, 2011.

36 Emma Boyle, 'UN declares online freedom to be a Human Right that must be protected', Independent, 5 July 2016, available at https://www.independent.co.uk/life-style/gadgets-and-tech/un-declares-onlinefreedom-to-be-a-human-right-that-must-be-protected-a7120186.html, accessed on 6 July 2020.

37 UN Human Rights Council Resolution on Protection of Human Rights on the Internet a milestone for free speech, says OSCE Representative', OSCE, 5 July 2016, available at https://www.osce.org/fom/250656, accessed on 8 July 2020.

38 The promotion, protection and enjoyment of Human Rights on the Internet, 27 June 2016, UNHRC A/HRC/32/L.20.

39 Lukasz Szoszkiewicz, 'Internet Access as New Human Right? State of the Art on the Threshold of 2020', Adam Mickiewicz University Law Review p.50, volume 8, 2018.

40 Council Recommendation 2008/2160(INI) of 26 March 2009, on strengthening security and fundamental freedoms on the Internet [2010] OJ C $117 \mathrm{E} / 206$.

41 Abmet Yildirim v. Turkey, ECtHR, 2012, App no 3111/10.

42 Constitution of Greece, 1974, art. 5(2); Constitution of Portugal, 1976, art. 35; Constitution of Ecuador, 2008, art. 16.
} 
fundamental rights especially the right to freedom of speech and expression.

The Constitutional Council in France in 2009 declared that the free communication of ideas and opinions enshrined in the Declaration of Rights of Man and the Citizen of 1789 implied freedom to access online communication services which are important for the participation in the democracy and the expression of ideas and opinions. ${ }^{43}$ The court declared the internet as a fundamental human right while revising the infamous HADOPI law dealing with copyright theft. Further, in 2016 France enacted the Digital Republic Law which envelops various matters concerning digital rights including privacy, right to be forgotten, net neutrality etc. The law facilitates free access to public internet connections and guarantees unrestricted internet access to individuals facing financial difficulty. ${ }^{44}$

In the Indian context, in the decision of Anuradha Bhasin \& Ors $v$ Union of India, the Supreme Court in early 2020 held that the freedom of speech and expression and the freedom to practice any profession, carry on any trade, business or occupation over the medium of internet enjoys constitutional protection under Article 19(1)(a) and Article 19 (1) (g) of the Constitution of India. ${ }^{45}$ The Court further held that the restrictions on the internet have to follow the principles of proportionality under Article 19(2). The court, however, did not look into the question of access to the internet as an independent fundamental right since the foregoing question was not a part of the discussion pertaining to the case. In Faheema Shirin v State of Kerala, the High Court of Kerala recognized the right to internet access as a fundamental right forming a part of the right to privacy and right to education under Article 21 of the Indian Constitution. ${ }^{46}$ The Courts in the Indian scenario, therefore, have only considered right to internet access as forming a part of other rights within Article 19 and 21 so far and has not recognized the right beyond it.

The Costa Rican Constitutional Court in 2010 ruled in favor of internet access as a fundamental right that essentially facilitates the exercise of the rights such as the freedom of speech and thought, education, democracy, online public services, and access to information among many other rights. ${ }^{47}$ In 2017, the Supreme Court of Costa Rica further upheld and reiterated the right to internet access as a fundamental right and emphasized the state duty to facilitate and expand internet access. ${ }^{48}$ The

43 Conseil Constitutionnel [CC] [Constitutional Court] Decision, France, 10 June 2009, No 2009-580DC, Rec. 107 (Fr).

44 Olivier Proust, 'France Adopts Digital Republic Law', Fieldfisher, 4 October 2016, available at https:// www.fieldfisher.com/en/services/privacy-security-and-information/privacy-security-and-informationlaw-blog/france-adopts-digital-republic-law, accessed on 12 July 2020.

45 Anuradha Bhasin v Union of India, Supreme Court of India, 2020, AIR 2020 SC 1308.

46 Faheema Shirin v State of Kerala, Kerala High Court, 2019, (2) KHC 220.

47 Andres Guadamuz, 'Costa Rican court declares the Internet as a Fundamental Right', TechnoLlama, 2 October 2010, available at https://www.technollama.co.uk/costa-rican-court-declares-the-internet-asa-fundamental-right\#: : text $=$ Very $\% 20$ interesting $\% 20$ news $\% 20$ from $\% 20$ the, right $\% 20 \mathrm{in} \% 20$ ruling $\% 20$ $2010 \% 2$ D 012790. \&text $=$ Therefore $\% 2 C \% 20$ access $\% 20$ to $\% 20$ the $\% 20$ Internet $\% 20$ should $\% 20$ be $\% 20$ equivalent $\% 20$ to $\% 20$ those $\% 20$ rights., accessed on 12 July 2020.

48 Valdelomar and Sibaja v Costa Rican Superintendence of Telecommunications, Supreme (Court of Final Appeal) Costa Rica, 2017, Exp.,17-000191-0007-CO. 
decision was in the light of a case concerning fair use policy which permitted mobile companies to reduce the mobile internet speeds of users on which restrictions were placed by the court bringing it in line with the state obligation to ensure internet access. Therefore, France, India and Costa Rica have recognized the right to internet access as a fundamental human right associating itself with existing established fundamental rights as its enabler and subset thereby preventing an interpretation to arrive at recognizing the right as autonomous or independent from the aforesaid.

While looking at countries that have implemented positive policies to ensure access, Finland has played a proactive role in addressing the digital inclusionary agenda, whereby broadband access was recognized as a 'legal right' through an amendment of the Communications Market Act. ${ }^{49}$ The telecom operators who are designated as service providers are entitled to provide internet access of $1 \mathrm{Mbps}$ to all permanent residents and business offices at a reasonable price which was doubled to $2 \mathrm{Mbps}$ in 2015. ${ }^{50}$ Even the UK has recognized internet access as a 'legal right' and aims to provide fast and reliable internet connectivity to people. ${ }^{51}$ Similarly, the Spanish Law on Sustainable Economy in 2011 included broadband access as a universal service which stipulates the existence of a broadband connection at a speed of $1 \mathrm{Mbps} .^{52}$ Further, Italy came up with a Declaration of Internet Rights in 2015, which is a non-binding document recognizing the right to internet access as an independent fundamental right. ${ }^{53}$ Nevertheless, its non-binding nature and fallacies in implementation should not lead to disregarding the futuristic and progressive contents of the declaration. Therefore, the domestic laws are visibly filled with disparities when it comes to recognizing the status and ensuring legal protection of internet access.

\section{Internet Access as a Human Right: Is it Even Possible?}

\subsection{Conceptualizing a Human Right to Internet Access}

The orthodox way of conceptualizing human rights has been to develop well-reasoned arguments, to explain the kind of rights humans need to protect their most important interests, arising by virtue of their human nature. ${ }^{54}$ Once it is clear what rights should

49 Wendy Zeldin, 'Finland: Legal Right to Broadband for All Citizens', Library of Congress, 6 July 2010, available at https://www.loc.gov/law/foreign-news/article/finland-legal-right-to-broadband-for-allcitizens, accessed on 12 July 2020.

50 'Shaping Europe's digital future - Country Information - Finland', European Commission, available at https:/ / ec.europa.eu/digital-single-market/en/cxvaountry-information-finland, accessed on 13 July 2020.

51 Mark Kaufman, 'The UK calls internet access as a legal right like water and power', Mashable, 21 Dec 2017, available at https://mashable.com/2017/12/20/uk-decides-broadband-internet-is-a-legal-right, accessed on 13 July 2020.

52 OECD e-Government Studies, 'Reaping the benefits of ICTs in Spain: Strategic study on communication infrastructures and paperless administration', OECD Publishing, 2012.

53 Elisabetta Ferrari, 'Italy issues a declaration of Internet Rights- Now let's improve it', Center for Global Communication Studies, 4 August 2015, available at https://global.asc.upenn.edu/italy-issues-a-declarationof-internet-rights-now-lets-improve-it, accessed on 13 July 2020.

54 Steven Wheatley, The Idea of International Human Rights Law, Oxford University Press, UK, 1st edition, 2019, 
be classified as human rights, all the actors and agents with correlative obligations, including the State, are identified. More often than not, for scholars, the mainstream approach towards conceptualizing human rights has been to identify a distinct quality or feature that has been imparted upon a person, by virtue of their human existence. ${ }^{55}$ Griffin, for instance, argues for the conceptualizing of human rights as a secular expression of natural rights. ${ }^{56}$

Historically, the approach towards conceptualizing human rights has always been to emphasize natural rights. However, this emphasis upon natural rights has been questioned by several scholars, in light of the evolving nature of society and the law. In particular, this emphasis on natural rights has been criticized by the proponents of the political conception of human rights. ${ }^{57}$

The political conception of human rights requires emphasis upon the relationship between an individual and the state. ${ }^{58}$ Advocates of this approach include Michael Ignatieff, Thomas Pogge, John Rawls, Joshua Cohen, and Charles Beitz. ${ }^{59}$ However, despite the ongoing debate between the two, an ideal approach towards the determination of human rights would be for both to work in tandem. ${ }^{60}$ In view of which, this part shall first philosophically justify a human right to internet access, and then, owing to the contemporary status of various nations, politically conceptualize the same.

\subsubsection{Philosophical Justification for a Human Right to the Internet: John Finnis and the Interests-based Approach}

Proponents of the interests-based approach to human rights opine that the objective of a human right is to protect certain essential human interests. In other words, justification of human rights would entail securing those essential human interests. Amongst many advocates of this approach is John Finnis. Belonging to the school of natural rights, he argues that a human right would be justified if it secures the necessary conditions for human well-being. ${ }^{61}$ Pertinently, while identifying what would constitute human well-being, Finnis identifies seven interests, which, as he posits, are fundamental to human well-being, and thus need to be protected by appropriate rights. These seven interests are 'life', 'knowledge', 'play', 'aesthetic experience', 'sociability', 'practical reasonableness' and 'religion'. ${ }^{62}$

In the backdrop of the COVID-19 pandemic, it has become more and more evident

p. 22.

55 ibid.

56 James Griffin, On Human Rights, Oxford University Press, UK, 2008, p. 32.

57 Anita Sophia Horn, 'Moral and Political Conceptions of Human Rights: Rethinking the Distinction', The International Journal of Human Rights p. 724, volume 20:6, 2016.

58 Kenneth Baynes, 'Toward a Political Conception of Human Rights', Philosophy and Social Criticism p. 371, volume 35:4, 2009.

59 Baynes (n 58), p. 375.

60 Ibid, p. 375.

61 John Finnis, Natural Law and Natural Rights, Oxford University Press, UK, 2011.

62 Ibid, p. 85. 
that these seven interests identified can only be secured by way of internet access. For instance, with regard to 'life', Finnis suggests that the term signifies all aspects of vitality, and includes bodily and mental health. ${ }^{63}$ As highlighted in the previous part of the paper, the pandemic has led doctors to conduct medical appointments to provide treatment via the internet, and many have even started seeking online mental health treatment, due to the lockdowns imposed in various nations. ${ }^{64}$ Moreover, it is also only through internet access that many have been able to secure the interest of 'sociability' by connecting with friends and relatives while staying locked inside their homes. Similarly, other examples can be witnessed in the form of online sermons ${ }^{65}$, and educational institutions conducting online classes. ${ }^{66}$

Considering that the internet is palpably the only resource to secure the seven interests identified by Finnis, during the pandemic and even in the post-pandemic world, ascertaining a human right to internet access has become a necessity in attaining the aforesaid interests, thereby securing the conditions for human well-being as posited by Finnis. However, considering the contemporary situation of many nations, the aforesaid right would also need to be politically conceptualized.

\subsubsection{Political Conception of a Human Right to the Internet: Using Charles Beitz's Tro-Level Model}

While adopting a pragmatic approach, Beitz proposes a two-level model towards conceptualizing human rights. ${ }^{67}$ This model has three elements. The firstelement signifies what Beitz considers human rights. He argues that a human right is a requirement, the purpose of which is to protect urgent individual interests against certain predictable dangers. ${ }^{68}$ Beitz opines that an urgent interest would be an interest that is recognized as important for typical lives, in contemporary society. ${ }^{69}$ It is pertinent to note that his model severely emphasizes the security of urgent interests, which is also what John Rawls emphasizes. ${ }^{70}$

Furthermore, Beitz calls the aforesaid certain predictable dangers 'standard threats'. According to Beitz, a 'standard threat' is any threat that is reasonably predictable under the social circumstances in which the right is supposedly operating. ${ }^{71}$ As has been highlighted in the previous chapter, it can not only be reasonably predicted that without internet access these interests would be severely threatened, but owing to various state practices pertaining to restrictions over internet access, these interests have already begun to be threatened, and would further continue to be threatened. A human right

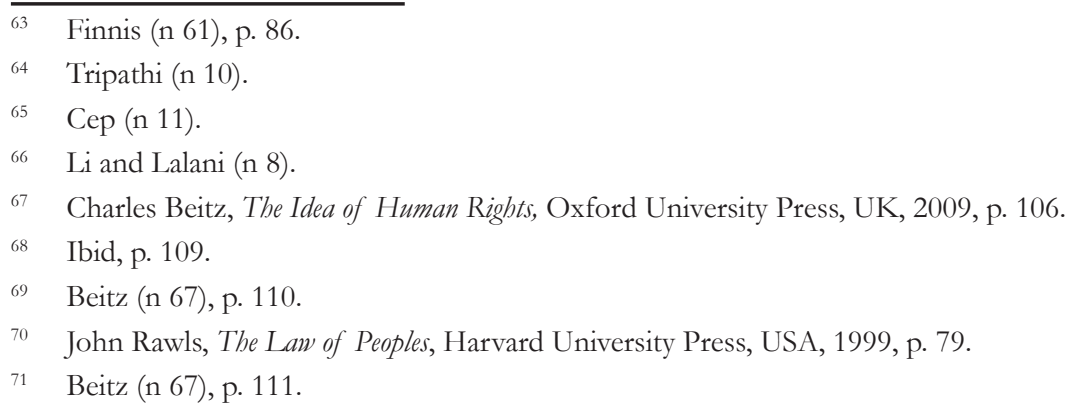


to internet access thus would protect these urgent interests, thereby fulfilling the requirements of a human right under Beitz's model.

The second element of his model suggests that human rights apply, in the first instance, to the political institutions of states. In other words, it is the state that first needs to respect human rights. This is the first level of his 'two-level model. Beitz posits that such 'first level' application includes respecting the underlying interests and aiding those who are non-voluntary victims of deprivation. ${ }^{72}$ Notably, he further argues that if a government of a state fails in such first-level application, then it contributes to the violation of human rights. As is evident, the COVID-19 pandemic has victimized millions globally. In addition to this, governments across various nations are imposing shutdowns on the internet or are not providing internet access, at a time where almost every aspect of a basic life requires the same. Owing to which, under Beitz's model, such state practices would be contributing to the violation of human rights, and thus would entail external intervention, or as Beitz posits, 'second level' operations.

In order to prevent the violation of human rights due to state practices, the third element of Beitz's model suggests that human rights are matters of international concern. $^{73}$ This is the second level of his 'two-level model. He opines that the incapability of a government to protect the underlying interests of its citizens should entail external interference, in the form of 'appropriately placed and capable' agents of the international community. ${ }^{74}$ Considering the human rights "violations" due to contradictory state practices, it is contended that the international community must respond to such practices, and facilitate the protection of the human rights of people all over the world. In light of this, this paper argues for an international human right to internet access. In view of the Beitz Model, an international human right to internet access would therefore not only oblige a state to provide internet access but would also provide for the international community's support towards protecting the threatened and urgent individual interests.

\subsubsection{Other Authors and Attempts to Argue for a Right to Internet Access: Craweford and Wang}

It is pertinent to mention that the argument for having a human right to internet access is not a novel one. ${ }^{75}$ For instance, Colin Crawford argues for a right to internet access, by highlighting the implications of internet exclusion. ${ }^{76} \mathrm{He}$ argues for the right to internet access, in light of the privatization of the internet. Notably, since he looks at the problem from a national perspective, he opines that public accommodation law is the legal vehicle for establishing that right. However, the purpose of using public

\footnotetext{
$72 \quad$ Beitz (n 67), p. 109.

73 Ibid.

74 Ibid.

75 Ryan Shandler and Daphna Canetti, 'A Reality of Vulnerability and Dependence: Internet Access as a Human Right', Israeli Law Review p. 77, volume 52, 2019.

76 Colin Crawford, 'Cyberplace: Defining a Right to Internet Access through Public Accommodation Law', Temple Law Review p. 225, volume 76, 2004
} 
accommodation law, as he argues, is the need for regulation of cyberspace. Furthermore, he pertinently identifies the digital divide as a crucial implication of internet exclusion. ${ }^{77}$

Xiaomei Wang adopts a 'Gewirthian approach' towards the right to internet access. ${ }^{78}$ She uses Alan Gewirth's Principle of Generic Consistency to argue that a right to internet access is not only possible but is also necessary. She opines that the right would be a mixed right, i.e., a positive as well as a negative right. However, in contradistinction to the present argument, she argues for a human right to internet access which can be derived from the human right to democracy.

\subsection{Internet Access as an Independent Human Right}

The argument for the elevation of the right to internet access as an autonomous right is directly proportional to the growing dependence on the digital world. Even though the dynamic growth of technology in the past few decades automatically attracted mass usage and reliance on internet technology, the pandemic climate has indeed overhauled the nature and urgency of this dependency. ${ }^{79}$

The critics of this argument contend that the internet should not be an independent human right as it is only an enabler of other rights, and is not a right in itself. ${ }^{80}$ Vinton Cerf, one of the 'fathers of the Internet' argued that for something to be regarded as a Human right, it must be among the things humans need in order to lead a healthy and meaningful life. ${ }^{81}$ Such arguments would have thrived in the past. However, it cannot sustain in the post-pandemic world in light of the utility internet access has shown to possess, as discussed in the previous chapters. While the internet was more of an auxiliary right in the past, in the post-pandemic world internet must be considered as an autonomous right in itself.

The justification for the internet as a stand-alone right flows from a twofold argument that firstly, no existing right is capable enough to protect this human right and secondly, the right meets the adequate threshold of importance. ${ }^{82}$ Until recently, the right to internet access was inseparably associated and coexisting with the right to freedom of speech, right to association and right to participation in democracy among other rights. ${ }^{83}$ The significance of the right emerged from the inability to attain optimum

Ibid, p. 238.

78 Xiaomei Wang, 'A Human Right to Internet Access: A Gewirthian Approach', Frontiers of Pbilosophy in China p. 652, volume 11:4, 2016.

79 'Corona Virus: Access to Internet can be a matter of life and death during a pandemic', Article 19, 31 March 2020, available at https://www.article19.org/resources/access-to-the-internet-can-be-a-matter-oflife-and-death-during-the-coronavirus-pandemic, accessed on 15 July 2020.

80 Brian Skepys, 'Is there a Human Rights to the Internet?', Journal of Politics and Law, volume 5, 2012.

81 Vinton, G. Cerf, Internet Access is not Human Right, The New York Times, 4 January 2012, available at https://www.nytimes.com/2012/01/05/opinion/internet-access-is-not-a-human-right.html, accessed on 20 January 2021.

82 Cali (n 34).

83 Andra Iftimiei, 'Evolution of the Fundamental Human Rights and Freedoms Catalog: Access 
utilization of the preceding rights in the absence of internet access. ${ }^{84}$ However, digital technologies which were only one of the means to achieve primary rights have evolved to become the portal to a virtual world that exists to substitute an inaccessible physical world during a pandemic. One should not overlook the fact that internet technology has transformed the personal device to become a school, college, office, grocery store, voting station, hospital, entertainment center, and many more things. ${ }^{85} \mathrm{It}$ is no longer confined to the effective utilization of existing rights, rather the only means for the realization of rights which cannot be availed through any other means. This leads to the cessation of the application of existing human rights provisions to afford effective protection to internet access as a right.

Another approach suggested by the scholars for the realization of the right to independent internet access is its possible emancipation from Article 15 of the ICESCR that established the right to benefit from scientific progress and its applications. ${ }^{86}$ This approach is similar to how scholars interpreted the elevation of the right to water as a human right. ${ }^{87}$ Even though the article does not specifically mention the 'internet', it clearly fits the contents of the provision since the internet is an application of scientific progress. ${ }^{88}$ The report of the special rapporteur in the field of cultural rights for the purpose of implementing Article 15 recognized the need to protect the freedom of access to the internet while maintaining the open architecture of the internet in order to uphold the right of people to science and culture. ${ }^{89}$ However, this recognition cannot be said to protect internet access holistically, since it is only a corollary to cultural and scientific rights focusing upon access to information and expression in the online sphere. Be that as it may, Article 15 can be an effective tool in the future to give recognition and secure the status of the right once the emancipation of internet access as a stand-alone right is complete. Therefore, in this context, the first argument that no existing human right is adequately protecting the right to internet access is satisfied.

The second argument that internet access meets the adequate threshold of importance to become an independent right is substantiated by the reliance on internet access as a basic need and shifting focus to the context of the pandemic. According to James Nickel, human rights are not ideals of the good life for humans, rather they are concerned with

to the Internet', Revista de Drept Constitutional p.2017, volume 48, 2017; Hillary Rodham Clinton, 'Internet Freedom and Human Rights', Issues in Science and Technology p.45, volume 28, 2012.

84 Ryan Shandler, Michael L. Gross \& Daphna Canetti, 'Can you engage in Political Activity without Internet? The Social effects of Internet Deprivation', Political Studies Review p. 1, 2019; Young Joon Lim, 'Internet as a Human Right: A practical Legal Framework to Address the Unique Nature of the Medium to Promote Development', Washington Journal of Law, Technology \& Arts p.296, volume 7, 2012.

85 Jack J. Barry, 'Covid-19 exposes why Access to Internet is a Human Right', Open Global Rights, 26 May 2020, available at https://www.openglobalrights.org/covid-19-exposes-why-access-to-internet-is-human-right/, accessed on 10 July 2020.

86 Jacopo Coccoli, 'The Challenges of New Technologies in the Implementation of Human Rights: An Analysis of Some Critical Issues in the Digital Era', Peace Human Rights Governance p.223, volume 1, 2017.

87 Szoszkiewicz (n 39).

88 Ibid.

89 Report of the Special Rapporteur in the field of Cultural Rights, The right to enjoy the benefits of scientific progress and its applications, 2012, UNHRC A/HRC/20/26. 
ensuring the conditions, negative and positive, of a minimally good life. ${ }^{90}$ Therefore, in the digital age, internet access has become a sufficiently urgent interest to justify regarding it as a human right because such access is currently necessary for securing important features of a minimally decent life. ${ }^{91}$

The proposal of Michael Best more than a decade ago to regard 'internet as a human right in and of itself' was rather futuristic. ${ }^{92}$ According to him, the symmetric information right to some extent requires the internet and thus access to the internet itself has become a human right, and therefore, to be excluded from the information technology is to be effectively excluded from information. ${ }^{93}$ Even though his views have been criticized for the lack of a systematic basis for the claim of Human Rights, this concept can be revisited to adapt and apply to the pandemic scenario where internet technology is the major means to information and being excluded from information poses an extreme threat to an individual's health and life itself. ${ }^{94}$

A debate on right to electricity considered it as a 'derived right' for attaining other basic rights and further stated that it gives access to improved material conditions but its absence does not make life necessarily unlivable. ${ }^{95}$ Applying this analogy directly to interpret the right to internet access will flaw the argument made in this paper, and hence, 'context' should essentially be a part of how human rights should be interpreted from a global perspective. ${ }^{96}$ Until recently, in some parts of the world, the internet was a luxury that was an alternate means of access to existing rights. However, the present pandemic backdrop transformed it into a basic necessity essential for sustaining life. ${ }^{97}$ This essentially satisfies the second criteria that the right to internet access meets an adequate threshold of importance to classify as an independent right.

The inclusion of internet access as an autonomous human right will be consequential in recognizing the prominence of the right which is no longer limited to achieving few other rights. This measure will lead to achieving uniformity in state practices and help to solidify and promote the international language of internet access as a human right in local discourses. ${ }^{98}$ It is especially relevant since countries are imposing

\footnotetext{
90 James Nickel, Making Sense of Human Rights, Oxford: Wiley-Blackwell, 2007.

91 Merten Reglitz, 'The Human Right to Free Internet Access', Journal of Applied Philosophy p.1, 2019.

92 Shandler and Canetti (n 75).

93 Michael L. Best, 'Can the Internet Be a Human Right', Human Rights \& Human Welfare p.23, volume 4, 2004.

94 Xiaowei Wang, 'Time to think about Human right to Internet Access: A Beitz's Approach', Journal of Politics and Law p.67, volume 6, 2013; Madeeha Majid, 'The Right to Internet as the Right to Health? Obligations to remove barriers to access of information during a pandemic', Leiden Law Blog, 16 April 2020, available at https://leidenlawblog.nl/articles/the-right-to-internet-as-the-right-to-health-obligations-to-removebarriers-to-the-access-of-information-during-a-pandemic, accessed on 15 July 2020.

95 Lars Lofquist, 'Is there a Universal Human Right to Electricity', The International Journal of Human Rights p. 711, volume 24, 2020.

96 Ibid.

97 Barry (n 85).

98 Rachel George, 'The Impact of International Human Rights Law Ratification on Local Discourses on Rights: The Case of CEDAW in Al-Anba Reporting in Kuwait, Human Rights Review p.43, volume 21, 2019.
} 
internet shutdowns and are failing to cater internet services to a large majority of the population during a pandemic. Moreover, there will be stronger and more effective measures towards implementation which can mend the digital divide that is successively deepening the offline inequalities. ${ }^{99}$

\section{Conclusion}

Against the backdrop of the ongoing COVID-19 pandemic, this paper is an attempt to argue for the establishment of access to the internet as an independent human right, since it has become an immensely vital aspect of basic human existence. It first highlights how internet access is increasingly relied upon by educational institutions, workplaces, religious institutions, medical professionals, and state governments, to continue their operations and provide their services.

The paper then focuses on instances of state-imposed internet shutdowns in India, Bangladesh and Myanmar to highlight the severe implications of the absence of internet access during the ongoing pandemic. Secondly, the paper provides a philosophical justification for establishing internet access as a human right and then uses Beitz's twolevel model to politically conceptualize the same. It further argues for establishing it as an independent human right since existing rights are inadequate to afford its effective protection in light of the unjustified internet shutdowns during such pandemics.

Although there are many nations where people have embraced the lockdowns, and digitization has become the "new normal", there are also nations where people are not only locked inside their homes but are also unable to exercise even the basic human rights that are required for their survival during the pandemic, and even in the postpandemic world. The COVID-19 pandemic has shown that internet access is not only limited to accessing information and individual expression. In light of this, it is urged that the time to establish internet access as an independent human right has indeed arrived. Nevertheless, on recognition of such a right, the implementation of the same remains with the state. It needs to be seen how effectively the state will discharge this obligation considering the infrastructural, financial and political challenges involved which would vary from state to state.

$99 \quad$ Eleanor Sarpong, 'Covid-19 shows why internet access is a basic right. We must get everyone connected', World Wide Web Foundation, 15 April 2020, available at https://webfoundation.org/2020/04/covid-19shows-why-internet-access-is-a-basic-right-we-must-get-everyone-connected/, accessed on 17 July 2020. 